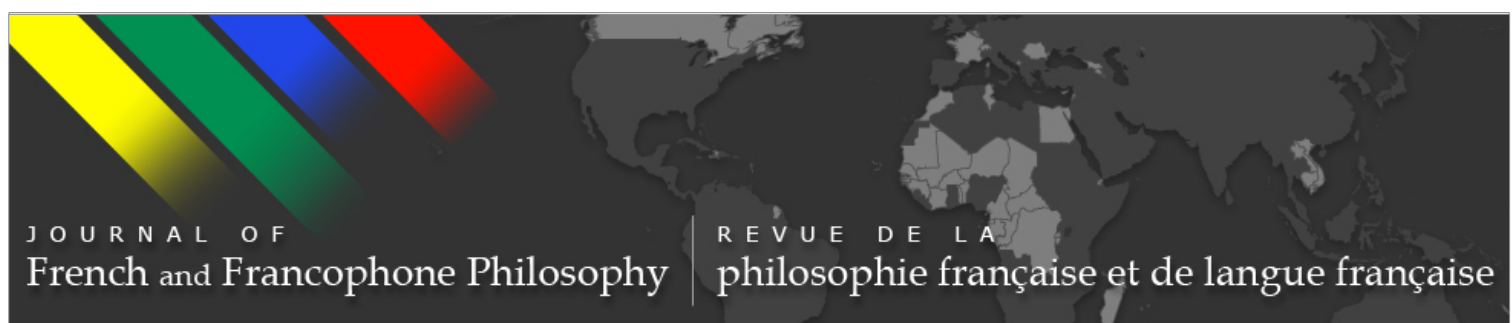

\title{
On Kristeva's Fiction
}

\section{Benigno Trigo}

Journal of French and Francophone Philosophy - Revue de la philosophie française et de langue française, Vol XXI, No 1 (2013) pp 60-82

\author{
Vol XXI, No 1 (2013) \\ ISSN 1936-6280 (print) \\ ISSN 2155-1162 (online) \\ DOI 10.5195/jffp.2013.569 \\ www.jffp.org
}

\section{(oc) $\mathbf{E Y - N C - N D}$}

This work is licensed under a Creative Commons Attribution-Noncommercial-No Derivative Works 3.0 United States License.

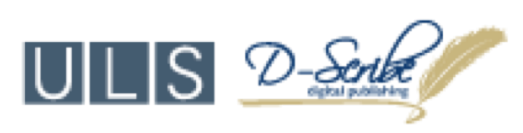

This journal is operated by the University Library System of the University of Pittsburgh as part of its D-Scribe Digital Publishing Program, and is co-sponsored by the University of Pittsburgh Press 


\title{
On Kristeva's Fiction
}

\author{
Benigno Trigo \\ Vanderbilt University
}

Over the years, Kristeva has given many interviews, where she has been asked the same question, "why a novel"? Her answers can be summarized into three related groups that eventually take us back to her initial response. The first group of answers brings Kristeva's novels back to her work with melancholy patients rather than to her research on melancholia. Kristeva answers that her fiction is a response to the psychoanalytic session. More specifically, fiction acts for her as an antidote to the depressing effect of encountering the disillusioned knowledge of her patients. It gives her the energy, renewal, and revitalization necessary to continue her psychoanalytic work as an analyst: "When I wrote The Samurai I believed that working on the novel would allow me to continue listening to my patients in a way that was attentive, inventive, and receptive to them and to their symptoms," she says in a 1990 interview with Elisabeth Bélorgey. ${ }^{1}$ The second group of answers to the question "why a novel?" suggests that writing fiction is an advanced, progressive, and perhaps speedier way into the unconscious, for Kristeva: "In comparison, the ability of theoretical discourse to take on métaphore and intrigue seemed to be far behind the form of the novel," she says in a 1992 interview with Bernard Sichére, suggesting that by giving form to, and enacting the essence of, the unconscious, fiction takes her further in her thinking than theory. ${ }^{2}$

But it is only in a later interview with Pierre-Louis Fort, conducted in 2005, and only in an oblique way, that Kristeva suggests that her fiction is an effect of the psychoanalytic session. Rather than an antidote against the depressive effects of therapy on the analyst, or a more progressive way to the unconscious, Kristeva instead suggests that fiction is a "propitious place" generated by the transference and counter-transference with her patients. ${ }^{3}$ In keeping with her latest work on forgiveness, Kristeva describes her fiction as an oneiric and safe place that is not judgmental, and that is a necessary complement both to her own ambivalent relationship to her origins, and to her violation of a certain trust. ${ }^{4}$ Suggesting that her "integration" in France and the European Union, as well as the fact that she

Journal of French and Francophone Philosophy | Revue de la philosophie française et de langue française Vol XXI, No 1 (2013) | www.jffp.org | DOI 10.5195/jffp.2013.569 
rarely speaks Bulgarian (a language that she no longer knows how to write) is a "betrayal," Kristeva describes her fiction as a liberation from the daily discipline that ensures her assimilation." She says "I am made of this Orthodox sensibility, and if I discipline it in the daytime, I am submerged in it at night: my unconscious is an Orthodox land enveloped by a French atmosphere." ${ }^{6}$

In this sense, Kristeva's decision to write novels becomes the obverse of the so-called "betrayal" of her Orthodox past, and opens a space for the paradoxical return of a mother tongue that she no longer writes. ${ }^{7}$ Describing the language of Stephanie Delacour (the narrator of her novels and her alter ego) Kristeva says "she does not inhabit the phonemes and syntax of the French language...but she writes the melody of the sensory that flows beneath her sentences." ${ }^{8}$ Writing fiction then becomes for Kristeva a complement to the "integration to the French language" that she had sought fifteen years earlier. In other words, Kristeva's decision to write fiction becomes an act that neither fights, nor submits to, her "betrayal," that is, to her integration and assimilation into another culture. From this perspective, Kristeva's decision to write novels is an act of psychoanalytic forgiveness, or what Kristeva calls a "pardon" (par, through, don, a gift), that interprets, or elaborates in writing, her "betrayal," an unconscious hatred that makes Kristeva betray her origins.

It is fair to say that Kristeva's turn to fiction has not been well received, particularly when it is compared to the reception of her turn to psychoanalysis. ${ }^{9}$ When Fort points out in 2005 that after three novels, "the doors to the literary temple...opened for Murder in Byzantium," Kristeva answers: "The 'literary world' disgusts me, and I hear the bluntness of that remark, but why retract it? I will never be part of that world, and it doesn't want me either." ${ }^{10}$ Kristeva's rejection of the "literary world" makes it clear that she is sensitive to the way her novels have been read, in spite of her claim in an interview from 1992 that she is not concerned with whether her novels attract readers, and in spite of her remark that "it is enough [for her] that the novel is disturbing." 11 Given Kristeva's description of her fiction as a forgiving response to her choice to make a life in the culture and language of France, it is perhaps understandable that she replies with anger to her socalled exclusion from the "literary world" of that country. ${ }^{12}$

\section{Kristeva's novels}

Kristeva published her first two novels The Samurai in 1990, and The Old Man and the Wolves in 1991. The Samurai narrates the interconnected lives, adventures, and transformations of three women (Olga Morena, Carole Benedetti, and Joëlle Cabarus) living in Paris, over a period of twenty years, from the student revolts of 1968 to the beginning of the AIDS epidemic at the end of the eighties. It describes their active participation in the intellectual debates, social and cultural turmoil of the times, and traces some

Journal of French and Francophone Philosophy | Revue de la philosophie française et de langue française Vol XXI, No 1 (2013) | http://www.jffp.org | DOI 10.5195/jffp.2013.569 
of the implications of the latter for their lives and loves with changing partners, which comprise a varied roster of men including a novelist, a professor, a painter, and a psychiatrist, among others. Most importantly, it follows the development of two of these women into writers: Joëlle, a psychoanalyst, and Olga, a graduate student in linguistics and literature.

The Samurai engages with contemporary political events and finds their origins in "an unknown force that causes us to act." ${ }^{13}$ Published in 1990, three years after the end of a period of "Cohabitation" (1986-1988) between the Socialist president François Mitterand and the Right-Wing Prime Minister Jacques Chirac, the novel re-inscribes the events of 1968 into the political landscape of France at a time when (Kristeva tells us) political leaders "didn't want people to link the disruption of France in 1968 and the socialist victory of $1981 .{ }^{\prime 14}$ From this angle, the novel also reads as a reevaluation of the legacy of 1968 for the steady movement of the country toward the political center, together with the marginalization of the Communist Party, implicitly arguing against the opinion that "attributes to '68 the economic crisis and unemployment which ravaged families, especially the least well-off ones." ${ }^{15}$ It is a personal and a critical account, written as a roman-à-clef, of events that contain for Kristeva the complex message of 1968 that "We aren't done with deciphering." ${ }^{16}$ In fact, the anamnesic exercise results in a meditation about writing as a means to access a force, an energy, and a rhythm that is described as a "seizure" in the novel and that seems to drive both the private struggles and the public duels of French intellectuals like Olga Morena, and perhaps Julia Kristeva herself. But the novel can be also read as a summary of the past, a settling of accounts in an effort to prepare for what is to come. From this perspective, the pessimistic tone and abrupt ending of the novel is also an expression of skepticism regarding the ability of utopian and masterful forms of engagement with this force (perhaps exemplified by the events of 1968), as well as an implicit call to write, act, and analyze in a different way. ${ }^{17}$

Kristeva changes the direction of her writing in The Old Man and the Wolves, away from the roman-à-clef and toward the genre of detective fiction. Juliana De Nooy emphasizes the search for truth in Freudian psychoanalysis and detective fiction as developed first by Edgar A. Poe: "Both psychoanalysis and detective fiction promote an interpretative practice that is attentive to clues, to the uncanny, and to the pathological. Both seek truth through the rehearsal of past events." ${ }^{18}$ But Stephanie's theory of crime is slightly different from this practice. She says it is "something like The Murders in the Rue Morgue." ${ }^{19}$ And indeed, Kristeva through Stephanie will criticize a disembodied view of language and truth, and the mode of analysis leading to it. Stephanie's reference to "The Murders in the Rue Morgue" signals Kristeva's account of language and truth as embodied still, as still troubled by contradictory passions and disturbing sensations, as well

Journal of French and Francophone Philosophy | Revue de la philosophie française et de langue française Vol XXI, No 1 (2013) | http://www.jffp.org | DOI 10.5195/jffp.2013.569 
as Kristeva's own development of a mode of analysis (or detection) informed and sustained by the passions and sensations of the body. ${ }^{20}$

Similar to The Samurai, The Old Man has implications for historical events. Published in 1991 after the death of her father in a Bulgarian hospital shortly before the fall of the Berlin wall in 1989, The Old Man picks up where her first novel (published only a year earlier) leaves off. As allegory, the novel can be interpreted to demystify a turning point in the history of the Cold War, and to bear witness to an increase in violence that paradoxically results from the historical fall of the wall. ${ }^{21}$ The Old Man represents the reach of the unleashed violence, which kills the symbolic father, the master analyst of Freudian psychoanalysis represented by Septicius Clarus, and makes it necessary to think again about the sources and origins of the violence, as well as about the best way to approach it. The novel also dramatizes the birth of a phoenix from these ashes, the emergence of the first-person narrative voice and character of Stephanie, a different kind of investigator and analyst who does not shy away from crime, evil, and violence, but rather finds her own origins as a detective in Dupin's animal thinking, and in the Orang-Outang's sadomasochistic repetition of an earlier scene with his master. Moreover, Stephanie becomes a detective who is prepared to talk about a mother tongue that she traces back to the sadomasochistic embrace and flagellation at the center of Poe's story.

As the title of Kristeva's next detective novel suggests, Possessions (1996) continues the investigation of the widespread "killer instinct" that drives the dueling characters of The Samurai, and the haunting passion at the center of The Old Man. This second installment of the adventures of the journalistcum-detective, Stephanie, transforms the earlier instinct and sordid passion into a "spirit" or "demon" that possesses the inhabitants of the fictional Santa Varvara and drives them first to murder, and then to decapitate Stephanie's friend, Gloria Harrison (not unlike the Orang-Outang disposes of the mother in Poe's story, Madame L'Espanaye). In later works, Kristeva suggests that this spirit is also an image of decapitation that possesses her as well as her mother. She states that she wrote the novel after being possessed by a decapitated woman, ${ }^{22}$ that she is the headless woman in the novel, ${ }^{23}$ and that the fantasy goes back to a drawing by her mother that she often remembers. ${ }^{24}$ Kristeva goes on to suggest that the novel works through this possession by coming closer to its disturbing image, by becoming more familiar with it, by studying and analyzing it like a detective in a roman noir. $^{25}$

Similar to the two previous novels, Possessions is also inflected by contemporary history and politics, even as the novel interrogates the sources of both. Kristeva writes the novel during a decade of consolidation by the extreme right in France. It is published in 1996, one year after the National Front, presided by Jean-Marie Le Pen, "sets a new record for the far right in a French national election," rising to prominence on a wave of anti-

Journal of French and Francophone Philosophy | Revue de la philosophie française et de langue française Vol XXI, No 1 (2013) | http://www.jffp.org | DOI 10.5195/jffp.2013.569 
immigration sentiment by garnering $15 \%$ of the vote in the first round of the 1995 presidential election. ${ }^{26}$ Significantly, the political platform of the National Front included reinstating capital punishment after its abolition in 1981, and it influenced the focus of the eventual winner, conservative Jacques Chirac, who turned his attention to "immigration, crime, and national identity." 27 Stephanie's investigation of the decapitation of her foreigner friend Gloria, can be interpreted as an investigation not only of this growing anti-immigration sentiment, but most importantly of the widespread turn "to crime," and of the wish to return to capital punishment by French society. In an essay on the visual representations of the guillotine during the French Revolution, Kristeva states that the death penalty is synonymous with decapitation in France, and that both "sinister events" are examples of what she calls "works in noir:" pre-historic acting-out rituals that include the totemic feast. ${ }^{28}$ For Kristeva, the erasure of the guillotine from the national consciousness has paradoxically prepared its return in full force, and a novel like Possessions reads partly as an attempt to analyze the origin and the fantasies of a "killer instinct" that leads a majority of the population in 1972, and then again in 1993, to express support for the death penalty. ${ }^{29}$ From this perspective, the novel is an investigation into the way to control, or cope with this insistent desire, not by disavowing it, but by representing it, by learning to speak its sinister language. Such investigations into what Stephanie calls the language of the mother's womb, can (paradoxically) set the conditions of possibility for a different social, cultural, and political beginning, one unlike the rudimentary and impoverished State that follows orgies of violence such as the guillotine or the death penalty. This beginning would be based instead on both Stephanie's linguistic analysis, and on the representation of a dark possession that leads to the matricide and decapitation of an innocent foreigner.

More so than in her earlier novels, narrators and readers alike of Murder in Byzantium (2004) repeatedly find themselves asking the question "Where am I?" 30 Maria Margaroni answers by claiming that we are in melancholy contemplation of death in the form of widespread crime, which paradoxically succeeds in animating redemptive hope in us. ${ }^{31}$ But if the novel places us at a crossing that produces hope, this hope depends on something other than crime or death. There is something alive (if strangely so) at this crossroads for Kristeva. There is a trace of life, a miasma-like remainder, the ignis fatuus from a dead sensation, the revolting material of the lost mother tongue, that Stephanie's "gruesome" ${ }^{32}$ form of detection reveals as a "feu follet" (a will-o-the-wisp). ${ }^{33}$ In Murder Kristeva tells the reader of the growing need to spin out fantasies from this seemingly intractable and expanding darkness. And analysis in the novel is both a police investigation, and a form that this fantasy can take: a turbulent (rhythmic) voyage or journey through the landscape of the psyche in an effort to re-write meaning back into it. From this perspective, both Santa

Journal of French and Francophone Philosophy | Revue de la philosophie française et de langue française

Vol XXI, No 1 (2013) | http://www.jffp.org | DOI 10.5195/jffp.2013.569 
Varvara and Byzantium become versions of Freud's Eternal City, ${ }^{34}$ and inversions of his infamous "dark continent." ${ }^{35}$ (Indeed, Kristeva's "mother tongue" can be interpreted as an inversion of Freud's unintelligible "Minoan-Mycenaean," an inversion that turns on the signifying point of darkness). In short, Murder shows the way in which the unconscious processes screened by the obscure spaces of noir detective fiction can return meaning to the depleted life of Santa Varvara's inhabitants.

Murder (2004) was published three years after the attacks by Al Qaeda in 2001 which destroyed the World Trade Center in New York City, and one year after the 2003 invasion of Iraq by the United States and a "coalition of the willing," which caused much damage to that Middle Eastern country, and fractured the former alliance between the United States and the European community. As such, Murder broadens Kristeva's analysis in Possessions of what she calls the "national depression" and its "manic manifestation in [French] nationalism" ${ }^{36}$ to include an analysis of the symptoms of what she calls "our dark times," and in particular of the underlying causes of the so-called "clash of religions" ${ }^{\prime 37}$ or the "clash between fundamentalisms" represented by these geopolitical events. ${ }^{38}$ Again, Kristeva's literary work takes us back to the meaning of the "killer instinct," the "dark passions," or the "demons" in the earlier novels. Here it is imagined as a question of place, the question of the point of negativity, instability and reversibility that is at the origins of characters like Sebastian Chrest-Jones and Xiao Chang (a bastard and a foreigner respectively).

\section{The Book Reviews}

All of Kristeva's novels have been translated into English within a short period of their publication in French, and they have all received a fair amount of attention in the popular press, both in French and in English. ${ }^{39}$ The international media gave much attention to Kristeva's first novel, with reviews and interviews in Paris's Le Monde, London's Times Literary Supplement and The Independent, as well as in New York's Village Voice. Notably, her later novels have not received the same kind, or the same amount, of attention. Perhaps this relative lack of interest in her later novels is explained by the fact that the reception that the international media gave Kristeva's first novel was not positive. Indeed, it would be generous to characterize it as mixed, abounding as it was in left-handed compliments like Lucy Hughes-Hallet's remark "Phillip Roth (who has a walk-on part in Les Samourais) has called Sollers 'an intellectual clown', and Kristeva too, combines a formidable brain with a certain playfulness." 40 More characteristic of the scathing tone of the majority of the reviews of Kristeva's novels is the opening sentence of Richard Gher's review of novels by Kristeva and Sollers: "What a couple of remarkable sellouts." ${ }^{41}$ In fact, much of the negativity directed at Kristeva's first novel seemed to be the result of her association with Phillipe Sollers (her husband) and with the intellectual

Journal of French and Francophone Philosophy | Revue de la philosophie française et de langue française Vol XXI, No 1 (2013) | http://www.jffp.org | DOI 10.5195/jffp.2013.569 
group that she portrayed in that first book, as suggested by Elaine Showalter's ironic description of Kristeva as "one of the most versatile stars of the international post-structuralist circuit." ${ }^{42}$

There have been fewer reviews of Kristeva's later novels, but they have been somewhat less critical than those of The Samourai. In fact, both Possessions and Murder in Byzantium have received some positive reviews. ${ }^{43}$ And as we have seen, Fort has even suggested that "the doors to the literary temple" opened for Kristeva's latest novel, referring to its reception in Le Monde, La Vie, La Croix, Le Point and Metropolis. However, a broader look at the reviews of Kristeva's novels still reveals a mixed reception at best, and one that tends to describe them as reactionary, difficult to read, and boring.

Politically, many reviewers consider Kristeva's novels to be conservative on several counts. These include a suspicion of the autobiographical nature of much of her fiction, which is interpreted as a turn away from social and political concerns. ${ }^{44}$ Both Hughes-Hallet and Gher consider Kristeva to have sold out to Western European bourgeois values, and implicitly appear to criticize her turn away from her Eastern European upbringing under Communism. Others, more "feminist" in their approach, find a nostalgic, if not reactionary, return to the family, motherhood and patriarchy in her novels. ${ }^{45}$ From a stylistic point of view, some reviewers complain that her novels do not satisfy the reader's desire for succinct and direct prose, referring to Kristeva's forays into history or philosophy as boring digressions that one reviewer describes as "breathless blather." ${ }^{46}$ Others describe her novels as poorly crafted, either because they breach the strict conventions of a literary genre, or because they do not meet the reviewer's expectations of verisimilitude. Declaring herself to be a lover "of realist novels like Balzac's, Stendhal's and Flaubert's," Kaylie Jones of the Los Angeles Times "yawn[s] of boredom" when reading The Samourai. ${ }^{47}$

Perhaps the negative reception by the popular press of Kristeva's novels can be explained, in part, as the shortcoming of a book market driven by economic forces that puts a premium on so-called "liberal ideas, simple pleasures, and clarity," the latter understood as a transparency achieved by staying close to familiar conventions. But the truth is that Kristeva's theory is also often criticized by feminist and post-feminist critics for being politically conservative, and it is also the target of a broader cultural impatience with the substance and style of so-called "high theory" in general, and of psychoanalysis in particular - including, by the way, the theoretical approach of those who criticize Kristeva's theoretical work. ${ }^{48}$ In his book review, Michael Wood points out the "tragic sense of life" that runs through Kristeva's Old Man and the Wolves as well as through her two books on Marcel Proust. Wood calls their harshness both "cozy" and "unadventurous," and states that "if Lukacs spoke of modern philosophers as living comfortably in the Grand Hotel of the abyss; the Freudian story can look like setting up house in a rat-trap." ${ }^{49}$

Journal of French and Francophone Philosophy | Revue de la philosophie française et de langue française

Vol XXI, No 1 (2013) | http://www.jffp.org | DOI 10.5195/jffp.2013.569 
It might be accurate to say that Kristeva's poor reception by the popular media is a reaction to the theoretical and psychoanalytic content of Kristeva's novels. Most reviewers don't see, or comment on, the connection between the novels and the theory, but nevertheless it seems to influence their descriptions of her novels as obscure, ponderous, and boring. Many reviewers have instead focused on putting Kristeva's novels in a literary context. Despite some minor disagreement, they place the first novel within the genre of the roman à clef, and the rest within detective fiction. Characteristically, most reviewers have negatively compared Kristeva's novels to two successful examples of both genres: Simone de Beauvoir's award winning The Mandarins, 1954; and Umberto Eco's bestseller The Name of the Rose, 1984.

\section{The Academic Critics}

Twenty years after Kristeva published The Samourai, academic critics are beginning to take stock of the reception of her fiction, and their assessment is twofold. They claim that critics have neglected Kristeva's fiction for the most part, and that those that have paid attention are confused by it. ${ }^{50}$ Some, like Bianca Rus, have gone so far as to make the more extreme claim that Kristeva's "fiction has been conspicuously neglected, if not completely ignored." ${ }^{51}$ Noting the "perplexity" of the few critics who do read her novels, Rus also describes their reactions as marked by "confusion and frustration." ${ }^{52}$ My study of more than twenty five book reviews could be said to contradict both claims, since Kristeva's fiction has received substantial attention from the media and from the international press, and instead of expressing confusion or frustration, the attention of the press has been straightforwardly negative for the most part. What is to be made, however, of the reception by the academic community? Is the assessment of neglect and confusion an accurate description of how critics in academic journals have read Kristeva's fiction?

On the subject of strict quantity, the more than twenty academic articles I examined appear to contradict the assessment of the critics. There is some truth to their claim, however, if by "confusion" the critics mean that the reviewers in the popular press mostly give a negative assessment of the novels (some going so far as to caricaturize them), while the studies by the critics in the academic journals tend towards a more serious, sustained, and forgiving approach to the novels, one that suggests a more positive reception. Contrary to the way Kristeva's novels have been read in the popular press, most academic reviewers insist on their link with her theory in general, and with her psychoanalytic theory in particular. One could even describe some of these academic readings of Kristeva's novels as oblique apologies of her theory, defending Kristeva against the accusation (both in the popular press, and in academic journals) that her theory is amoral and even reactionary, an accusation perhaps best represented by Wood who

Journal of French and Francophone Philosophy | Revue de la philosophie française et de langue française Vol XXI, No 1 (2013) | http://www.jffp.org | DOI 10.5195/jffp.2013.569 
writes in the London Review of Books "Stéphanie Delacour...believes that...We need not good and evil but the difference between them. This isn't 'essentially amoral,' it's just alarmingly reactionary." ${ }^{53}$

Much of the critical commentary about Kristeva's novels is more informed about (and more sympathetic to) her overall psychoanalytic project than the reviews. And much of it also appears to be written in answer to the similar critiques of Kristeva's theory that appeared in academic journals between 1989 and 1990, by Judith Butler, Teresa de Lauretis, and Nancy Fraser, all of them written before the publication of Kristeva's first novel. ${ }^{54}$ For these academic readers familiar with Kristeva's psychoanalytic theory, the practice of writing fiction is therapeutic at a personal level, but more significantly, it is also loaded (some might say fraught) with social and political implications. Thus, Colin Davis suggests that Kristeva's fiction is a "gift of meaning" that helps us to confront, displace, and forgive our individual and social criminal desires, and Kristeva's novels represent her encouragement of individuals to heal their communities one story at a time. Davis also interprets the novels as a call for a broader social commitment to encourage and support the act of storytelling: "The profusion of narratives and the effects of transference whereby each story becomes the story of another correspond to the analyst's gift of meaning. Through this gift, something like the understanding of the other can be achieved," Davis concludes. ${ }^{55}$

From this perspective, the writing of fiction in general, and of Kristeva's analytical or psychoanalytic mode of fiction writing in particular, can be a gift, a cure, a return to the act of imagination, fantasy and representation, though, for some it can also be a pharmakon delivering us to our self-destructive drives and to an illusion of clarity and revelation. But for the most part, academic critics see a certain antidote in Kristeva's writing. They see Kristeva's novels as a mode of treatment for an individual (and for a collectivity) that suffers from a psycho-social melancholy, which stems in part from a depressive economy at the foundation of subjectivity (itself imbued with what Freud called the death-instinct), but also in part from the pulverizing catastrophes of the twentieth century (e.g., Hiroshima, Auschwitz, the Gulag, the Cold War, and 9-11-2001). Following Kristevan psychoanalysis, most of these critics believe that these traumatic and catastrophic experiences have carbonized the imaginary. That is, they have shut down our ability to imagine, to elaborate our constitutive traumatic experiences, threatening instead to destroy the antidote necessary to overcome the trauma of being in general, but also the particular nature of the trauma that the speaking subject suffers due to sexual difference, and thanks to the effect of this difference on our relations to the maternal body. ${ }^{56}$ Both for Kristeva, and for these academic critics, the act of writing and reading (and of writing and reading what Kristeva calls "poetical detective novels") becomes the origin of (and the necessary condition for) all other

Journal of French and Francophone Philosophy | Revue de la philosophie française et de langue française Vol XXI, No 1 (2013) | http://www.jffp.org | DOI 10.5195/jffp.2013.569 
ethical and political acts. ${ }^{57}$ By putting us in contact with an other (who is also in ourselves), the act of writing and reading offers the promise of renewal, and psychoanalytic forgiveness, necessary to overcome the trauma of our death instinct, and the catastrophes of the twentieth century. ${ }^{58}$ As Davis suggests, Kristeva's novels are proof of the fact that "the desire to kill is not the last word," at least not yet. ${ }^{59}$

For many of these critics, Kristeva's novels are laboratories for personal therapy where the writer gets in touch (so-to-speak) with her death-drive, or at least keeps open the border to the bodily drives. ${ }^{60}$ They are critiques of, and antidotes for, the society of the spectacle, critiques and antidotes based on self-analysis. ${ }^{61}$ From their perspective, Kristeva's novels can restore to health the social "paternal function" ${ }^{62}$ by insisting on a retelling of our myths ${ }^{63}$; they can change the view of Europe by generating new allegorical illusions ${ }^{64}$; they can remap our cultural memory by displacing and translating the unconscious ${ }^{65}$; they can restructure and repair our relationship with our fundamental separations, breaks, and splits, including those from the mother tongue ${ }^{66}$; they can be acts of forgiveness beyond the death instinct, and beyond the violence that is at the origins of our selves, and of our social bonds according to psychoanalysis ${ }^{67}$; and as such they can move us towards an ethics based on compassion, or a humanism based on forgiveness, an ethics and a humanism which accommodates the exiled nature of the human experience. ${ }^{68}$

While this overall positive assessment puts the academic critics at odds with the reviewers of Kristeva's fiction, there are important points of agreement between them as well. Not surprisingly, and given the psychoanalytic approach of many of these critics, they agree with the reviewers that the nature of Kristeva's novels is profoundly autobiographical. But the critical commentary has also developed an aspect of Kristeva's autobiographical fiction that is absent from the reviews. These critics focus on the references in Kristeva's novels to her vexed identity, to her separation from her country of origin, and to her disturbing mother tongue, calling attention to the political problems of assimilation and exile that these references suggest. ${ }^{69}$ Some of these critics put Kristeva's fiction in the literary context of exile novels by Nancy Houston and Ilija Trojanov. ${ }^{70}$ Others apply Kristeva's theoretical notion of the semiotic to the linguistic experience of bilingual code-switching in the United States. ${ }^{71}$ Not surprisingly, this critical assessment of Kristeva's fiction appears after border studies and bilingualism became legitimate fields of study in the United States, and after the publication of Possessions in 1996, a novel about the beheading of a translator.

Similarly, Juliana De Nooy writes about Kristeva's novels in the context of Kristeva's theory of translation of bodily drives, comparing the vexed experience of moving from one language to another to the similarly disturbing movement between semiotic and symbolic modes of signification.

Journal of French and Francophone Philosophy | Revue de la philosophie française et de langue française Vol XXI, No 1 (2013) | http://www.jffp.org | DOI 10.5195/jffp.2013.569 
E. Agoston interprets Kristeva's novel in the context of a nomadic experience caused by political and economic upheavals like the rise and fall of Communism under the Soviet Union. She points to the healing power of the novels that dramatize the suffering of the émigré, as well as the construction of an identity based on something other than the mother tongue. Also Valerie Raoul similarly puts Kristeva's novel in the context of bilingualism, and suggests that there might be a relation of identity between Kristeva's concept of matricide, and her acquisition of another language.

All of these academic critics echo Kristeva's own account of her novels in her interviews, as well as Kristeva's account of writing in the detective mode, as an investigation of the genesis of writing. ${ }^{72}$ From Kristeva's perspective, the writer is a melancholy analyst who investigates the genesis of her own writing, which is nothing short of an investigation into the origins of our selves, and of our social bonds. Like Freud in the story of the primal horde in Totem and Taboo, Kristeva finds a crime at the center of her stories of investigation. However, Kristeva also suggests in her interviews that the crime might not be so much the murder of the Father as the betrayal of the mother tongue, and that the writer forgives this betrayal even as she repeats it in her fiction. In this way, fiction writing for Kristeva has the potential of turning betrayal into renewal in a foreign language. Kristeva has referred to this process as a necessary translation, but also as a graft and a transfusion of the remains of the mother tongue on to the foreign language: "It is this double of language...that I have tried to translate...through the detective story," she says. ${ }^{73}$

The critical commentary on Kristeva's novels also reveals some persistent gaps in the commentary about her fiction. Perhaps one of the most intriguing of these lacunae concerns the theme of matricide in Kristeva's practice of fiction writing, and particularly in relation to her first novel. While The Samourai has elicited the most (and the most negative) responses from the international and popular press, it has received little critical attention in academic journals. ${ }^{74}$ Most of the critical commentary has focused instead on Kristeva's later detective fiction, and while the assessment of these novels has been favorable for the most part, the criticism surrounding The Samourai, though sparse, is negative. In fact, the negative assessment of Kristeva's first novel is one of the few points in which there is agreement between the reviewers in the popular press, and the critics in the academic journals.

In her essay, Davis refers to her preference for Kristeva's detective novels. She explains her relative lack of interest in The Samourai by pointing to the nature of the roman à clef as a genre based on facts. ${ }^{75}$ She suggests that as a critic interested in psychoanalysis she is less interested in facts than in the fantasies that we weave around the facts, and also in our ability to continue to produce such fantasies. But this explanation of her preference fails to convince mainly because it is based on a strict difference between the 
factual and the fantastic elaboration of those facts in literature that should be suspect to a psychoanalytic critic. Indeed, from the perspective of the psychoanalytic critic, a meaningful gray area separates fact from fiction, and the roman à clef should be just as interesting to her as the detective novel, if not more so, given the conventional disavowal of the porosity of this border by the autobiographical genre. ${ }^{76}$

Perhaps a more convincing explanation of Davis's preference (and of the similar preference of many academic critics) might be that The Samourai resists the reading that academic critics rehearse and repeat. In other words, The Samourai is not as willing an object of what Kelly Oliver has called a psychoanalytic social theory, as her later detective novels seem to be. ${ }^{77}$ That is, Kristeva's first novel appears to be resistant to a psychoanalytic social theory that defines fiction writing as an act that has a political effect on both the individual and society; or as a laboratory of writing, where the writer puts herself at risk; or as a journey to the dark continent of the unconscious as Kristeva might put it, where the antidote to our maladies might be found. Instead, The Samourai might read more like an example of a novel rigorously orchestrated to defend the self from such inquiries into the unconscious. It is, after all, a novel that looks back to a lost time, with more nostalgia than irony, with more regret and bitterness than self-awareness and self-criticism.

More to the point, The Samourai can be interpreted as a novel that performs a foundational matricide that the scanty criticism about The Samourai has seen, and described, but whose function has yet to be fully understood. Like the reviews before them, much of the criticism about the novel centers on the fact that The Samourai is Kristeva's reply to de Beauvoir's novel The Mandarins. And much of the criticism has argued that Kristeva's novel (sometimes described as if it were a copy) falls short of the accomplishments of the "original." But from the perspective of Kristeva's theory of matricide, and from her comments about the poetical detective novel, The Samourai is ripe for a study that searches for a symbolic matricide within that novel, a matricide that is necessary for the beginning of Kristeva's writing. ${ }^{78}$ From this perspective, The Samourai could be the novel that not only hides the "true crime" behind the mask of the roman à clef, but it also would be the foundational act that the subsequent detective novels both hide and reveal. That is, the first novel might best represent the matricide that the later novels elaborate, filled as they are with repeating references to symbolic parricides and castrations. Moreover, if The Samourai were understood as a foundational symbolic matricide giving birth to Kristeva's fiction writing, it also could be interpreted as the similarly abject pre-text to Kristeva's writing in a social-psychoanalytic mode. Perhaps this symbolic matricide at the center of The Samurai, Kristeva's betrayal of the original novel by de Beauvoir, but also her matricide in writing of her predecessor as an author, makes the novel universally unpalatable, mocked as it is, by the reviewers, and ignored as it is, by most academic critics.

Journal of French and Francophone Philosophy | Revue de la philosophie française et de langue française Vol XXI, No 1 (2013) | http://www.jffp.org | DOI 10.5195/jffp.2013.569 
Kristevan psychoanalysis suggests that it is difficult if not impossible to face the matricide at the center of our speaking subjectivity, and that we resort to all kinds of perversions to work through it. And it is a credit to Kristeva's focus, self-determination, and understanding of the vexed nature of our matricidal selves that she continues to write fiction even after the almost universally negative reaction to her first novel. ${ }^{79}$

Should we conclude, then, that Kristeva's fiction has been neglected or ignored, as some academic critics have noted? The fact is that Kristeva's fiction has received some attention by academic critics, though not as much as the attention it has received from reviewers in the popular press, and less attention by far than the academic critics have devoted to Kristeva's theory. ${ }^{80}$ Still, the respectable quantity of academic criticism devoted to her novels (one book and more than twenty essays over nineteen years), and the sophisticated nature of the analysis, would seem to suggest that academic critics have neither neglected nor ignored Kristeva's novels. The so-called "confusion" might be the result of mixing together the readings of two very different audiences publishing in two different venues: the popular press and the academic journal. Indeed, it seems that while most book reviewers are frustrated by the presence of theory in Kristeva's novels, many academic critics are instead frustrated by novels that are not "Kristevan enough." For example, Levenson asks, "where is the shock to father's law?" ${ }^{81}$ Because of a resistance to theory in general and to psychoanalytic theory in particular, book reviewers have tended to read Kristeva's fiction as narcissistic and selfcelebratory, as apolitical at best, and reactionary at worst. Academic critics, who are more receptive to both, have tended to see an attempt to explore and critique the self in Kristeva's fiction. And following the implications for our civilization of its discontents, psychoanalytic critics insist that Kristeva's fiction has political implications for the larger society because it helps us to confront the vexed desires at the origins of our social bonds, and because it helps us to tend to their potentially deadly effects, both on the individual and on the social collective.

Most book reviews have pointed to the autobiographical nature of the novels as evidence of Kristeva's ideological shortcomings, whether she is described as apolitical, anti-feminist, or bourgeois. Most academic critics, on the other hand, have offered a more positive interpretation of Kristeva's novels, interpretations that also address the characterization of her theory as both apolitical and anti-feminist. Many have focused on their autobiographical character in order to argue that the novels are relevant to debates ranging from immigration to exile and nationalism, as well as to the related issues of assimilation, integration, and transculturation and their often ambiguous effects.

Academic critics have expanded on the literary context of Kristeva's novels, making useful distinctions and establishing helpful differences between the genres. However, they have not offered a comprehensive

Journal of French and Francophone Philosophy | Revue de la philosophie française et de langue française

Vol XXI, No 1 (2013) | http://www.jffp.org | DOI 10.5195/jffp.2013.569 
account of her fiction writing, one that transcends the generic differences that seem to split Kristeva's works into two moments, the moment of the roman à clef exemplified by The Samourai, and the moment of detective fiction that seems to extend through the rest of her novels. But the work of the academic critics has gone some distance in echoing Kristeva's account of detective novels as an investigation into the genesis of writing.

\section{"Yes, but is Kristeva any good as a novelist?"}

I have tried to make the argument that there are two relatively discreet readerships for Kristeva's fiction so far, and that each group has a different opinion as to the worth of Kristeva's fiction depending on whether they assign value to her psychoanalytic theory or not. The book reviews eschew theory in general, and psychoanalysis in particular, and are negative by and large. The academic critics, by contrast, are open to theory and positive for the most part. But it is also true that the question of the value of Kristeva's fiction (closely followed by the related question "Would we read these books if they weren't by Kristeva?") is also asked by a wide array of readers who straddle these two groups: readers who are both theoretically informed and interested in literature, whatever the criteria used to assign literary value to it. For these readers, it is not enough to answer these questions by simply bracketing-out aesthetic value, based on universal categories such as beauty and perfect form. They also ask whether Kristeva's novels are more than "scholarship," more than "theoretical indirection or exploration." If, for example, they are a form of embodied detective fiction (as I suggest here), then does its corporeal supplement or excess satisfy as fiction? Simply put, does Kristeva's fiction "deserve to be read"?

These repeating questions, and others like them ("Is it really any good as fiction?" "Is it great literature?") are symptoms of what Kristeva is in fact trying to address. Kristeva urges her readers to go beyond these questions of so-called literary quality, and to experience writing that puts ideas at the same level as character, pacing, plot, suspense, form and style. What is at stake for Kristeva is precisely the ability first to read, and then to enjoy, such work. It is indeed a question of reading and enjoyment, and, more specifically, it is a question for Kristeva of the inability of the modern reader to enjoy the kind of experimental fiction that escapes easy definition and classification, and that has a reputation for being difficult to read. This fiction includes the so-called French intellectual novel, the Nouveau Roman, but also novels of contemporary writers like the Chilean Roberto Bolaños, whose works, for example, Michael Schaub describes as "flawless, majestic" but also as "hard to read." ${ }^{82}$ What makes such novels so hard to enjoy?

In her book New Maladies of the Soul (1993), Kristeva goes some distance in answering this question. In that book, Kristeva describes the effects of contemporary events like the Shoah, the deployment of the Atom bomb, but also the collapse of Communism, and the Fall of the Berlin Wall (1989) on

Journal of French and Francophone Philosophy | Revue de la philosophie française et de langue française 
our internal defenses, on what she calls the psyche or the soul. I believe that Kristeva refers obliquely to Europeans in that book, by referring to the analysis of a patient whose dreams and speech are like an "iceberg." Didier's dreams are monumental, cold, and they lie hidden just below the surface. His speech is visible but reduced, shrunk, hard and brittle, like the top of the iceberg. Didier's art is a set of monstrous collages, and each one represents a similarly frozen object that stands for his sense of self, his soul, or his psyche. Indeed, Didier is a figure for European man after the Cold War. He is unable to feel and transform something that is both inside and outside of him, something that is familiar, but that is nevertheless so disturbing that it freezes him, something as catastrophic as the mythical severed head of the Medusa. Paradoxically, the sudden loss of his defenses, like the sudden loss of the Berlin Wall, threatens to compound the catastrophe. The fall of the Berlin Wall is both a liberation and a threat to this man, who abruptly loses a reduced space, or a wall, that both separated and also connected (albeit thinly) the two sides of his split self, and his feelings from his language.

Although New Maladies is essentially a commentary on the effects of the Cold War on Europeans, it has broader implications that also affect readers outside the European community. Didier also could be a figure for Kristeva herself and for the contemporary reader in more general terms, in so far as they all uncomfortably and imperfectly straddle binaries that are at odds with each other: binaries such as feeling and language, theory and fiction, Eastern and Western Civilizations. The Berlin Wall could similarly be a figure for Kristeva's novels and for contemporary writing, in so far as they are similar defenses that both separate and connect the different sides of a split subject: a person split between Bulgaria and France, or a novel split between ideas and plot, for example. Could the modern reader of Kristeva's novels be cold to them because these novels mirror his frozen and split self? Is this the reason why he is unable to interpret, transform and then enjoy her novels, and why they are so hard to read? Perhaps. Sadly, the fact is that when these novels are simply dismissed as imperfect and boring, the defenses they represent don't disappear, instead they go underground and hide from our view, like the bottom half of an iceberg they can become more treacherous.

From this perspective, the modern reader suffers from a malady that makes him ask the same questions over and again; questions that presuppose the failure of such novels for not being literary enough, for being too philosophical and boring. These questions remind us that Kristeva is not an ideal author devoted to the craft of writing novels, and they are a symptom of our devotion to this ideal. In other words, these questions express our need and our desire to imagine ourselves in relation to an ideal object, and to remain stuck, frozen, in front of that freezing object. Kristeva, instead, asks us to move beyond this paralyzing ideal, and to do it for our own good.

Journal of French and Francophone Philosophy | Revue de la philosophie française et de langue française Vol XXI, No 1 (2013) | http://www.jffp.org | DOI 10.5195/jffp.2013.569 
Kristeva's novels urge us to stop idealizing and to start finding enjoyment in objects that are represented in a different way, in a way that is more enabling, more forgiving. They suggest that we model our reading after a different, docile, object. What is at stake for Kristeva is not to forgive a novelist for writing imperfectly, but to forgive the reader for being a perfectionist. Better yet, what is at stake is to continue to read imperfectly, with full knowledge of the fact that the reader cannot see in himself: the imperfection that the reader denies through what Kristeva calls idealization, the other side of abjection. By continuing to ask the question "Is Kristeva any good as a novelist?", we continue to tell ourselves that it is not possible that there is no ideal object. By describing her novels as boring, hard to read, "blather," we display the pleasure we feel when we protect the existence of an ideal object. Instead, we should try to ask different questions, such as whether Kristeva's novels liberate us from our tendency to idealize. How does Kristeva's blend of fiction and theory free us from our ideals? Does it allow us to overcome this punishing need? Kristeva's fiction provokes questions like these, and they in turn help us to move through and beyond the symptomatic question of literary value.

1 Elisabeth Bélorgey, “On the Samourai," in Interviews, ed. Ross Mitchell Guberman (New York: Columbia University Press, 1996), 251.

2 Bernard Sichére, "Interview: The Old Man and the Wolves," in Interviews, 164.

3 Julia Kristeva, Hatred and Forgiveness, trans. Jeanine Herman (New York: Columbia University Press, 2010), 297.

${ }^{4}$ In Hatred and Forgiveness, Kristeva gives a psychoanalytic account of forgiveness as analytical listening and interpretation "that neither judges nor calculates, but is content to untangle and reconstruct" the entangled loves and hatreds that constitute the psyche of the patient (Kristeva, Hatred, 194).

${ }^{5}$ In an answer to a question about the scant presence of signs of her Bulgarian past in her last novel, and referring to her fiction, Kristeva states "Is it because the voyage includes its share of betrayal?" suggesting that she betrays that past both in and outside her novels (Kristeva, Hatred, 300).

${ }^{6}$ Kristeva, Hatred, 301.

${ }^{7}$ Kristeva has said that she is not Catholic by background, and that her father was a very great believer in the Orthodox Church in Bulgaria.

8 Kristeva, Hatred, 301.

Journal of French and Francophone Philosophy | Revue de la philosophie française et de langue française Vol XXI, No 1 (2013) | http://www.jffp.org | DOI 10.5195/jffp.2013.569 
${ }^{9}$ This reception is ironic since, as I suggest below, her turn to fiction is but a mode of her turn to psychoanalysis.

10 Kristeva, Hatred, 283.

11 Sichére, “Interview," 166.

${ }^{12}$ Kristeva has published her novels with excellent presses suggesting that at least a part of the literary world embraces her writing.

13 Julia Kristeva, The Samurai, trans. Barbara Bray (New York: Columbia University Press, 1992), 43.

14 Julia Kristeva, Revolt, She Said, trans. Brian O'Keefe (Los Angeles: Semiotext(e), 2002), 14.

${ }^{15}$ Kristeva, Revolt, She Said, 28.

${ }^{16}$ Kristeva, Revolt, She Said, 28.

17 The Samurai ends with a reference to both Joelle Cabarus's and Olga de Montlaur's books. Olga's is titled The Samurai. With the end also come news of the death of Cabarus's father that stops her from writing in her journal.

18 Juliana de Nooy, "How to Keep Your Head When Everyone Else is Losing Theirs: Translating Possession into Revolt in Kristeva," in After the Revolution, On Kristeva, eds. John Lecthe and Mary Zournazi (Woolloomooloo, Australia: Artspace Visual Arts Center, 1998). 47-48.

19 Julia Kristeva, The Old Man and the Wolves, trans. Barbara Bray (New York: Columbia University Press, 1994), 177.

20 The reader will remember that Dupin, the detective in Poe's story, solves the mystery of the Rue Morgue by deducing with an animal intelligence described by the narrator as "diseased" and reverse (or "a-posteriori”), that an "Ourang-Outang" is responsible for the brutal murder of Madame L'Espanaye and her daughter (Edgar A. Poe, Great Short Works of Edgar Allan Poe, ed. G.R. Thompson [New York: Harper and Row, 1970] 145).

21 See Bové, Language and Politics in Julia Kristeva 123. Given the focus of this essay and the limitation of space, I can only make a gesture here to the fact that after the Berlin Wall falls, the influx of capitalist investment has a destabilizing effect on that city, which effect Kristeva dramatizes in her allegorical novel.

22 Julia Kristeva, Visions capitales (Paris: Adagp, Editions de la Reunion des musées nationaux, 1998), 45.

${ }^{23}$ Kristeva, Revolt, She Said, 70.

${ }^{24}$ Kristeva, Visions capitales, 13.

Journal of French and Francophone Philosophy | Revue de la philosophie française et de langue française Vol XXI, No 1 (2013) | http://www.jffp.org | DOI 10.5195/jffp.2013.569 
25

I borrow the term "roman noir" from Kristeva, who uses it to name a form of fiction writing that is breathless, anguished, and even totally crazy ("complètement givré”). See Julia Kristeva, "Meurtre à Byzance, ou Pourquoi 'je me voyage' en roman," in La haine et le pardon; Pouvoirs et limites de la psychanalyse III (Paris: Librairie Arthème Fayard, 2005), 619. Women writers of police investigations, Gothic novels, and modern whodunits excel in this form, which seeks to name a "sensorial enigma." Julia Kristeva, Le génie féminin: Colette (Saint-ArmandMontrond: Librairie Arthème Fayard, 2002), 163.

26 J.G. Shields, The Extreme Right in France: From Pétain to Le Pen (New York: Routledge, 2007), 251.

27 Shields, The Extreme Right, 252, 258.

${ }^{28}$ Kristeva, Visions capitales, 102.

${ }^{29}$ Kristeva, Visions capitales, 107. Since joining the European Union, France has become a part of a community of nations that agrees that the death penalty should be abolished worldwide. See Rita J. Simon, and Dagny A. Blaskovich, A Comparative Analysis of Capital Punishment (Lanham: Lexington Books, 2002), 20.

30 Julia Kristeva, Murder in Byzantium, trans. C. Jon Delogu (New York: Columbia University Press, 2006), 234.

31 Maria Margaroni, “Julia Kristeva's Chiasmatic Journeys: From Byzantium to the Phantom of Europe and the End of the World," in Psychoanalysis, Aesthetics, and Politics in the Work of Julia Kristeva, eds. Kelly Oliver and Stacy Keltner (New York: State University of New York Press, 2009), 117. In her essay, Margaroni studies Kristeva's notion of Europe, and characterizes Kristeva's detective fiction as a form of Benjaminean allegory (108).

32 Kristeva, Murder, 118.

33 Kristeva, Murder, 129.

${ }^{34}$ Sigmund Freud, The Freud Reader, ed. Peter Gay (New York: W.W. Norton and Company, 1989), 726.

35 Julia Kristeva, Thinking About Liberty in Dark Times: The Holberg Prize Seminar (Bergen: University of Bergen, 2004), 27.

${ }^{36}$ Kristeva, Thinking About Liberty, 22.

37 Julia Kristeva, “Thinking in Dark Times," Profession (2006): 16.

38 Kristeva, Thinking About Liberty, 32.

${ }^{39}$ Samurai was translated into English in 1992, Old Man in 1994, Possessions in 1998, and Murder in 2006.

Journal of French and Francophone Philosophy | Revue de la philosophie française et de langue française Vol XXI, No 1 (2013) | http://www.jffp.org | DOI 10.5195/jffp.2013.569 
40 Lucy Hughes-Hallet, “Egghead out of her shell; Julia Kristeva, once the darling of the Paris avant-garde, explains why she now thinks individuals are more interesting than isms," The Independent, Feb. 9 (1992): 26

${ }^{41}$ Richard Gehr, "A Man and a Woman," The Village Voice, Dec. 11 (1990): S31.

42 Elaine Showalter, “A Paragon and her Position," Times Literary Supplement, Sept. 28-Oct. 4 (1990): 1038.

43 See Ann Irvine, "The Old Man and the Wolves," Library Journal 119, 21 (December, 1994): 132; Brad Hooper, "Possessions." Booklist, February 15, 94, no. 12 (1998): 982; Mélanie Gleize, "En Croisade contre les croisés: Meurtre à Byzance de Julia Kristeva," Spirale, no. 201 (mars-avril 2005): 48-49; and Matt Thorne, "Killing in Theory and Practice; Murder in Byzantium by Julia Kristeva, trans. C Jon Delogu," The Independent, Friday April 7 (2006): n.p.

44 See Tony Judt, "The Samurai by Julia Kristeva," Book World XXII, 45, November 8 (1992): 6; and Sybil Steinberg, "Fiction: The Samurai by Julia Kristeva," Publishers Weekly 239, 39 (August 1992): 65-66.

45 See Anne Donadey, "Julia Kristeva, Le Vieil homme et les loups," The French Review 67, no. 1 (October 1993): 157; and Molly Hitte, “Yeah, Baby," The Women's Review of Books 24, no. 1 (Jan. - Feb. 2007): 26-27.

${ }^{46}$ Yvonne Zipp, "Page turners; Murder and intrigue span the globe, from Byzantium to Burundi. Who's guilty?" Reviewer Yvonne Zipp is on the case," The Christian Science Monitor, Feb 24 (2006): 13.

47 Kaylie Jones, “Psychoanalyst's first attempt at a novel inspires a yawn of boredom," The Los Angeles Times, March 1 (1993): E3. See also Ann Irvine, "The Old Man and the Wolves," Library Journal 119, 21 (December 1994): 132; Laurence Enjolras, "Possessions," The French Review 71 (March 1998): 676-67; and Merle Rubin, “Book Review: Detectable trouble in erudite mystery," The Los Angeles Times, Feb 28 (2006): E.8.

48 The most quoted feminist and post-feminist critiques of Kristeva's theoretical works are by De Lauretis, Fraser and Butler. See Teresa De Lauretis, "The Female Body and Heterosexual Presumption," Semiotica 67, no. 3-4 (1989): 259-279; Nancy Fraser, "The Uses and Abuses of French Discourse: Theories for Feminist Politics," Boundary 2 17, no. 2 (1990): 82-101; and Judith Butler, "The Body Politics of Julia Kristeva," Hypatia 3, no. 3 (Winter 1989): 104-118.

${ }^{49}$ Michael Wood, "Time of the Assassin," London Review of Books 17, 2, January 26 (1995): 18 .

Journal of French and Francophone Philosophy | Revue de la philosophie française et de langue française Vol XXI, No 1 (2013) | http://www.jffp.org | DOI 10.5195/jffp.2013.569 
50 See Szu-Chin Hestia Chen, French Feminist Theory Exemplified Through the Novels of Julia Kristeva; The Bridge from Psychoanalytic Theory to Literary Production (Lewiston: The Edwin Mellen Press, 2008), 19; and Michael Greaney, "Violence and the Sacred in the Fiction of Julia Kristeva," Theology and Sexuality 14.3 (2008): 294.

51 Bianca Laura Rus, "Remapping the European Cultural Memory: The Case of Julia Kristeva's Murder in Byzantium," Atlantis 35, no. 1 (2010): 16.

52 Rus, “Remapping," 16.

53 Wood, “Time," 18.

54 For examples of this type of sympathetic critical commentary, please see Amy Brooksbank Jones, "Julia Kristeva and Her Old Man, Between Optimism and Despair," Textual Practice 7, 1 (1993): 1-12; Vassiliki Kolocotroni, “A Little Inner Mythology: Kristeva as Novelist," New Formations 21 (1993): 146-158; Joan Kirkby, “Julia Kristeva: A Politics of the Inner Life?," in After the Revolution, On Kristeva, 109-123; and Rus, “Remapping," 15-24.

55 Colin Davis, "Psychoanalysis, Detection and Fiction: Julia Kristeva's Detective Novels," Sites 6, no. 2 (2002): 304.

${ }^{56}$ See, for example, Oliver's interpretation of Kristeva's Black Sun as a melancholy account of feminine sexuality "because the female infant cannot abject the maternal body without abjecting herself" (Kelly Oliver, ed, The Portable Kristeva (New York: Columbia University Press, 2002), 300.

57 Julia Kristeva, Colette, trans. Jane Marie Todd (New York: Columbia University Press, 2004), 119.

58 Referring to psychoanalytic forgiveness, Kristeva writes "In these postmodern times of religious clashes, which are times of endless war, it might be useful to remember that psychoanalytical interpretation, by revealing multifaceted hatreds, offers itself as the ultimate lucidity of pardon, which psychical life needs in order to continue living, quite simply, without necessarily absolutely ceasing to hate (Kristeva, Hatred, 194).

59 Davis, "Psychoanalysis," 304.

${ }^{60}$ For examples of this interpretation of Kristeva's novels, please see Kolocotroni, “A Little Inner Mythology," 146-158; Angela Tidmarsh, “Kristeva's Literary Interpretative Clinic," in After the Revolution, On Kristeva, eds. John Lecthe and Mary Zournazi (Woolloomooloo, Australia: Artspace Visual Arts Center, 1998), 133149; de Nooy, "How to Keep your Head," 47-61; and Greaney, "Violence and the Sacred," 293-304.

Journal of French and Francophone Philosophy | Revue de la philosophie française et de langue française Vol XXI, No 1 (2013) | http://www.jffp.org | DOI 10.5195/jffp.2013.569 
${ }^{61}$ Brooksbank, “Julia Kristeva and Her Old Man," 1-12 (passim).

62 In Desire in Language, Kristeva defines the paternal function as a "permanent gobetween" from an imaginary discourse of the self and a discourse of transcendental knowledge: "a pulsation of sign and rhythm, of consciousness and instinctual drive" (Julia Kristeva, Desire in Language; A Semiotic Approach to Literature and Art, ed. Leon S. Roudiez (New York: Columbia University Press, 1980),139.

63 Maria Margaroni, “The Trial of the Third: Kristeva's Oedipus and the Crisis of Identification," in julia kristeva; live theory, eds. Lecthe, John and Maria Margaroni (London: Continuum. 2008), 34-62 passim.

64 Kirkby, “Julia Kristeva,” 109-123 (passim); Margaroni, “Julia Kristeva's Chiasmatic Journeys," 107-124 (passim).

${ }^{65}$ Rus, “Remapping," 15-24 (passim).

66 de Nooy, “How to Keep Your Head," 47-61 (passim); and Valerie Raoul, “L'autre langue fécondatrice: 'l'étrangeite' en soi dans Instruments de ténèbres de Nancy Houston et Possessions de Julia Kristeva," in La Francophonie sans frontière: une nouvelle cartographie de l'imaginarie au féminin, eds. Lucie Lequin and Catherine Mavrikakis (Paris: L'Harmattan, 2001), 445-453.

67 Davis, “Psychoanalysis," 294-306 (passim).

68 Anna Smith, Julia Kristeva: Readings of Exile and Estrangement (London: Macmillan Press, 1996).

${ }^{69}$ See de Nooy, "How to Keep your Head," 47-61; E Agoston-Nikolova, "The World Is Vast: Bulgarian Exile Writers between Two Cultures," Studies in Slavic Literature and Poetics 34 (1999): 3-10; Raoul, “L’autre langue fécondatrice,” 445-453.

70 Agoston, "The World Is Vast," 3-10; Raoul, “L'autre langue fécondatrice," 445453.

71 Geraldine Kraver, "Revolution Through Poetic Language: Bilingualism in Latina Poetry from La Frontera," LIT: Literature, Interpretation, Theory 8, no. 2 (October 1997): 193-206.

72 Kristeva, Colette, 119.

${ }^{73}$ Kristeva, Hatred, 301.

74 The few examples of critical commentary in academic journals on The Samourai include: Paul Renard, "Des Mandarins aux Samouraïs, ou de l'engagement existentialiste à l'individualisme post-moderne," Roman 20-50 vol. 13 (June 1992): 111-24; Kolocotroni, “A Little Inner Mythology," 146-158; Michael Levenson, "The Critic as Novelist," The Wilson Quarterly 18, no. 1 (Winter 1994):116-124; and Margaret Atack, "The Silence of the Mandarins: Writing the Intellectual and May 68

Journal of French and Francophone Philosophy | Revue de la philosophie française et de langue française Vol XXI, No 1 (2013) | http://www.jffp.org | DOI 10.5195/jffp.2013.569 
in Les Samouraïs," Paragraph: the Journal of the Modern Critical Theory Group 20, no. 3 (1997): 240-57.

75 Davis, "Psychoanalysis," 299.

76 In the words of Carol Mastrangelo Bové, the narrators of the novel are "themselves fragments of the author's psyche" (Mastrangelo Bové, Language and Politics in Julia Kristeva, 98).

77 Kelly Oliver, The Colonization of Psychic Space: a Psychoanalytic Social Theory of Oppression (Minneapolis: University of Minnesota Press, 2003).

${ }^{78}$ A careful textual analysis would be necessary to prove this point, suffice it to say for now that at the end of the novel we learn that Olga Morena (one of Kristeva's alter egos) is the author of a book titled The Samurais and that the origin of Olga's writing is the archaic and matricidal struggle that also defines the Chinese. During an argument about the acquisition of language by the Chinese, Olga says to her husband: "And so a Chinese infant is involved very early on in the speech system; he's being formed and influenced by symbols as he drinks his mother's milk. He can speak and sing his intimate body battle with his mother - he doesn't have to bury it and wait until he's two years old to express it" (Kristeva, The Samurai, 192).

79 Carol Mastrangelo Bové's interpretation of Kristeva's first novel is one of the notable exceptions to this overall negative reaction (See Mastrangelo Bové, Language and Politics, 97-103).

80 There are more than a dozen books dedicated to the theoretical work of Kristeva including (in order of publication): A. White, "L'Eclatement du sujet": The Theoretical Work of Julia Kristeva. University of Birmingham Center for Contemporary Studies, 49, 1977; John Lechte, Julia Kristeva (London: Routledge, 1990); Kelly Oliver, Reading Kristeva: Unraveling the Double-bind (Bloomington: Indiana University Press, 1993); Anna Smith, Julia Kristeva: Readings of Exile and Estrangement (London: Macmillan Press,1996); Martha Reineke, Sacrificed Lives; Kristeva on Women and Violence (Bloomington: Indiana University Press, 1997); Anne-Marie Smith, Julia Kristeva: Speaking the Unspeakable (New York: Sterling, VA: Pluto Press, 1998); Noelle McAfee, Julia Kristeva (London: Routledge, 2003); Cecilia Sjoholm, Kristeva and the Political (London: Routledge, 2005); Miglena Nikolchina, Matricide in Language (New York: The Other Press, 2004); Carol Mastrangelo Bove, Language and Politics in Julia Kristeva (New York: State University of New York Press, 2006); and Stacy Keltner, Kristeva: Thresholds (London: Polity Press, 2011).

81 Levenson, "The Critic," 22. 
82 Michael Schaub, “Brutal and Perfect ‘Third Reich': Bolaño's Final Gift,” NPR, Nov.

17, 2011, http://www.npr.org/2011/11/17/142358687/brutal-and-perfect-thirdreich-bolanos-final-gift.

Journal of French and Francophone Philosophy | Revue de la philosophie française et de langue française Vol XXI, No 1 (2013) | http://www.jffp.org | DOI 10.5195/jffp.2013.569 